\title{
Characteristics of selected lakes with aeolian and karst genesis in the Holy Cross Region
}

\author{
Adam Choiński ${ }^{1, *}$, Artur Zieliński² \\ ${ }^{1}$ Department of Hydrology and Water Management, Adam Mickiewicz University, \\ Krygowskiego 10, 61-680 Poznań, Poland, e-mail: choinski@amu.edu.pl (*corresponding author) \\ ${ }^{2}$ Institute of Geography and Environmental Sciences, Jan Kochanowski University in Kielce, \\ Uniwersytecka 7, 25-406 Kielce, Poland, e-mail: artur.zielinski@ujk.kielce.pl
}

\begin{abstract}
In the belt of the Polish Uplands, including the Holy Cross Region, lakes occur sporadically. In some places, however, they are somewhat more abundant. They are usually objects with a small surface area. The majority of them have not been subject to thorough investigation. Therefore, the objective of the paper is the expansion of knowledge regarding these lakes. The paper among others presents the characteristics of several lakes with aeolian genesis located on the Przedbórz Upland in the catchment area of the Wierna River and in the Nida Basin near the towns of Busko-Zdrój and Pińczów. The study results determine the morphometric parameters of the lakes, also pointing to an exceptionally high variability of physical and chemical water properties, as well as the possibility of periodical disappearance of the lakes. Moreover, the study results provide a necessary and solid basis for further investigation of the lakes, which in the context of the observed increasingly serious water deficit and decrease in the level of surface waters and groundwaters is undoubtedly of high importance.
\end{abstract}

Key words: karst and aeolian lakes, lake morphometry, Holy Cross Region

\section{Introduction}

Lakes occur sporadically in the belt of the Polish Uplands (Choiński 1995), although the Holy Cross Region (Świętokrzyski Region) is not generally associated with lakes. In some places, however, lakes are somewhat more abundant, e.g. in the catchment area of the Wierna Rzeka River. As observed by Jaśkowski and Sołtysik (2000, 2001, 2003), the concentration of lakes in the Holy Cross Region can provide the basis for calling the area of their occurrence the "Holy Cross Lakeland". The authors also point out that the name can be used not in the regional sense, but only as a description of the area of occurrence of natural water bodies in a somewhat higher abundance, and with a specific coherent genesis associated with aeolian processes.

Another, more abundant group of lakes in the Holy Cross Region includes lakes with karst genesis. They are located in the northern part of the Nida Basin (Zieliński 2013; Stachura et al. 2018).
Due to the evidently progressing decrease in the level of surface waters and groundwaters, and increasingly longer periods with a deficit of precipitation waters, it is necessary to pay greater attention to any natural water bodies. Therefore, research has been conducted for the purpose of expanding knowledge regarding lakes with karst and aeolian genesis in the Holy Cross Region.

\section{Study area and methods}

The Holy Cross Region, which covers the area of the Holy Cross Voivodeship (Świętokrzyskie Voivodeship), is located in the middle part of the Polish Uplands, within Lesser Poland (Małopolska) Upland (Solon et al. 2018).

The study concerned three lakes with aeolian genesis: the lake in Michala Góra village - also called Lake Elżbiety (Fig. 1A), the lake in Fanisławice village, and Lake Zorawski Ług (Fig 1B). All of them are located in the Przedbórz Upland (Przedborska 
Upland) macroregion within the catchment area of the Wierna River (Fig. 2).

According to Jaśkowski and Sołtysik (2001), the origin of the lakes is associated with the Late Vistulian dune forming cycle. Dune complexes and individual dune landforms developed at this time, sometimes accompanied by deflation depressions. According to the aforementioned authors, in many cases bottoms of the depressions reached impermeable deposits, and as a consequence of an increase in groundwater level in the Holocene and surface water supply, lakes or wetlands developed in some of the depressions.

The second group of lakes under study includes lakes with karst genesis: the lake in Stawiany village, Lake Moczydło, and Lake Bronina (Fig. 1C). They are located in the Nida Basin, in the vicinity of the towns of Pińczów and Busko-Zdrój (Fig. 2).

The objective of the study was to investigate their morphometric characteristics and the properties of bottom sediments. Sediment sampling provided the basis for the determination of the depth of its deposition by means of a sonar and weights probe, and determination of the location of the sampling site by means of GPS. Temperature was also measured in the surface water layer and in the vertical profile, as well as $\mathrm{pH}$, oxygen content, and transparency by means of a Secchi disc. Moreover, $\mathrm{pH}$ of the sampled lake sediments was determined in a laboratory by means of the electrometric method, content of organic matter $\left(m_{\text {org }}\right)$ and ash $(p)$ by means of incineration in a muffle furnace at a temperature of $550 \mathrm{C}$, and content of calcium carbonate $\left(\mathrm{CaCO}_{3}\right)$ by means of the Scheibler method (Table 1$)$.
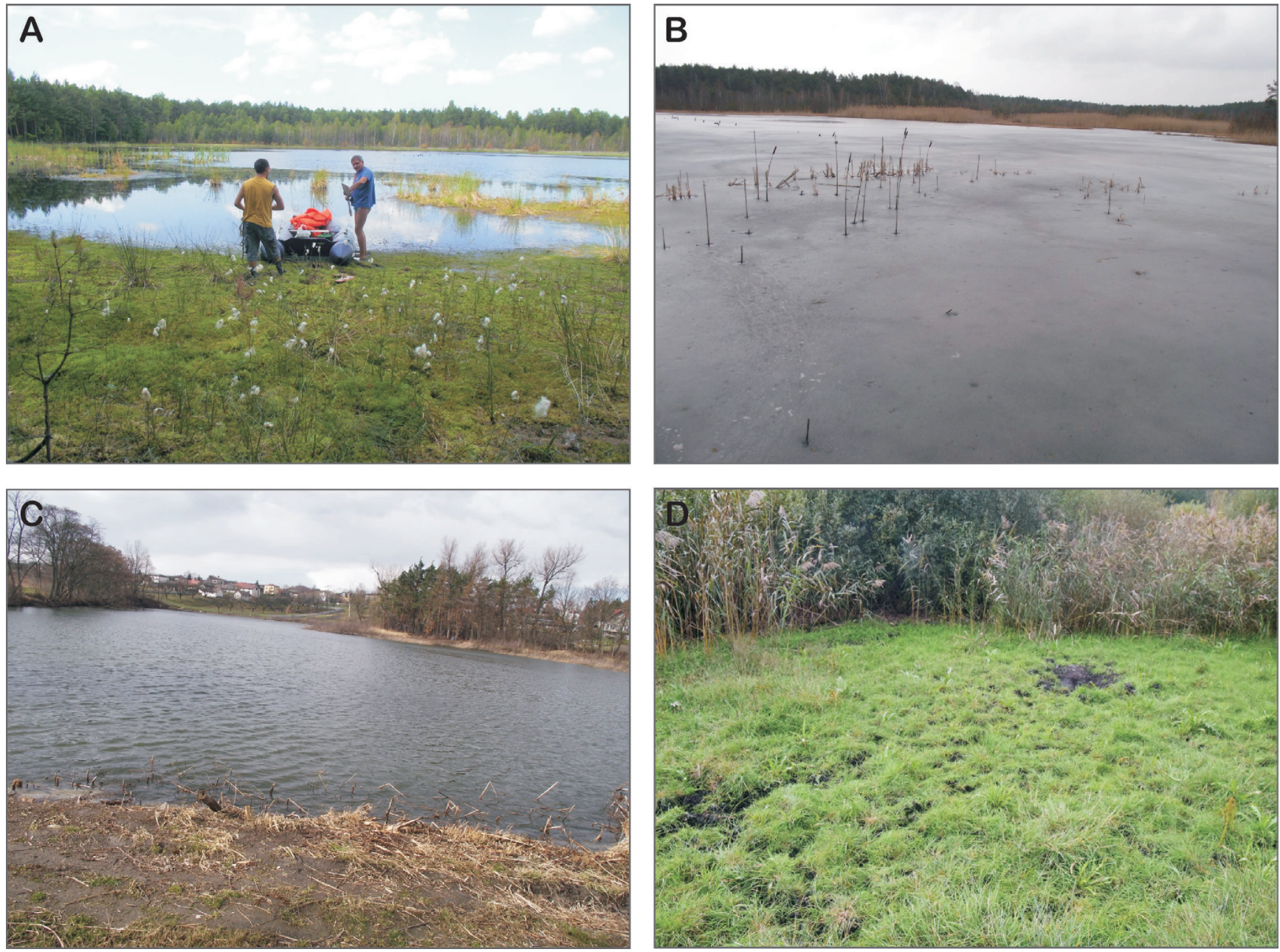

Fig. 1. General views of the studied lakes: A - lake in Michala Góra village (25 June 2011), B - Lake Zorawski Ług (2 March 2012 ), C - Lake Bronina (31 March 2012), and D - Lake Moczydło devoid of water (8 October 2019). Phot.: A. Zieliński (A-C) and J. Starus (D) 


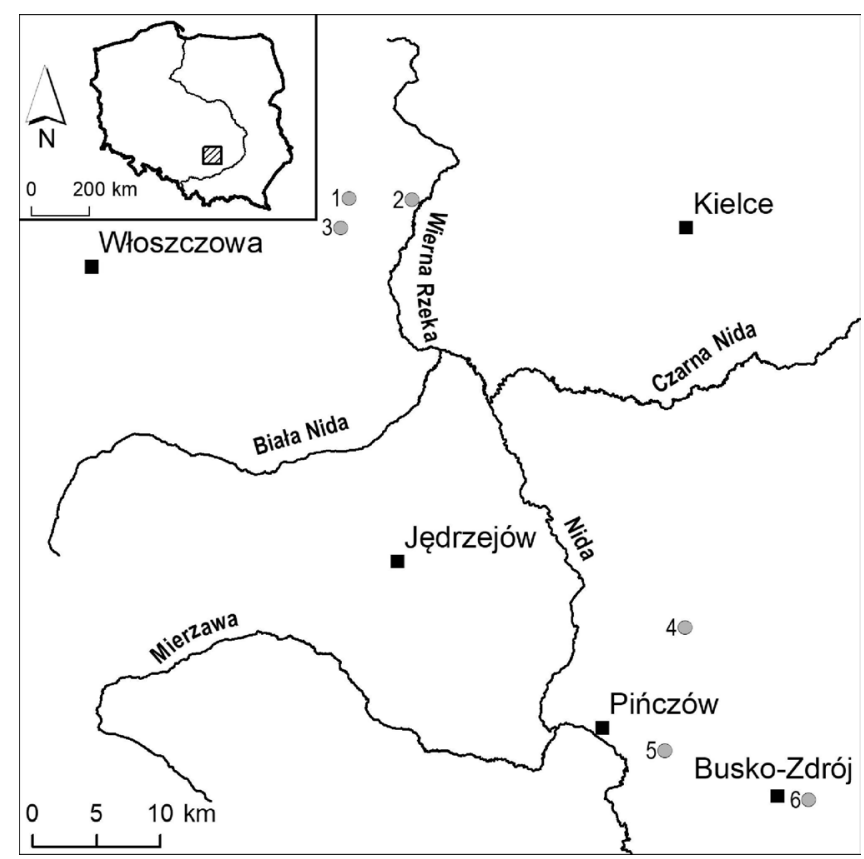

Fig. 2. Location of the studied lakes: 1 - lake in Michala Góra village, 2 - lake in Fanisławice village, 3 - Zorawski Ług, 4 lake in Stawiany village, 5 - Lake Moczydło, 6 - Lake Bronina

\section{Results and discussion}

The majority of lakes selected for analysis have never been subject to any detailed investigations. Only Biernat (2001) conducted some limnological research on the lakes with an aeolian origin. Biernat and Gwiazda (2003) then presented the morphometric parameters of Lake Ruda in the vicinity of Ruda Zajączkowska village, and Biernat and Sobieszczański (2003) gave the morphometric parameters of the lake near Michala Góra (Lake Elżbiety) while Kukiełka and Pieńkowski (2005) provided a brief description of lakes in the analysed area.

Only the lakes with karst genesis have been subject to more thorough studies (Zieliński 2010, 2013; Stachura et al. 2018). Kirviel et al. (2012) compared ice cover thickness in both aeolian and karst lakes in the Holy Cross Region. The results of the basic field and laboratory research are presented in Table 1.

Based on field measurements and cartographic materials, and particularly orthophotomaps from 2010, preliminary morphometric data of three of the studied lakes, namely Stawiany, Moczydło, and Bronina were collected for the first time, and bathymetric plans were developed for them (Fig. 3 ). This makes it possible to compare the morphometric parameters of these lakes with lakes located in other regions of Poland, for example: Choiński and Ptak (2009), Choiński et al. (2014) and Choiński et al. (2016).

Table 2 presents data for the lake in Michala Góra, in the literature known as Lake Elżbiety (Bier-

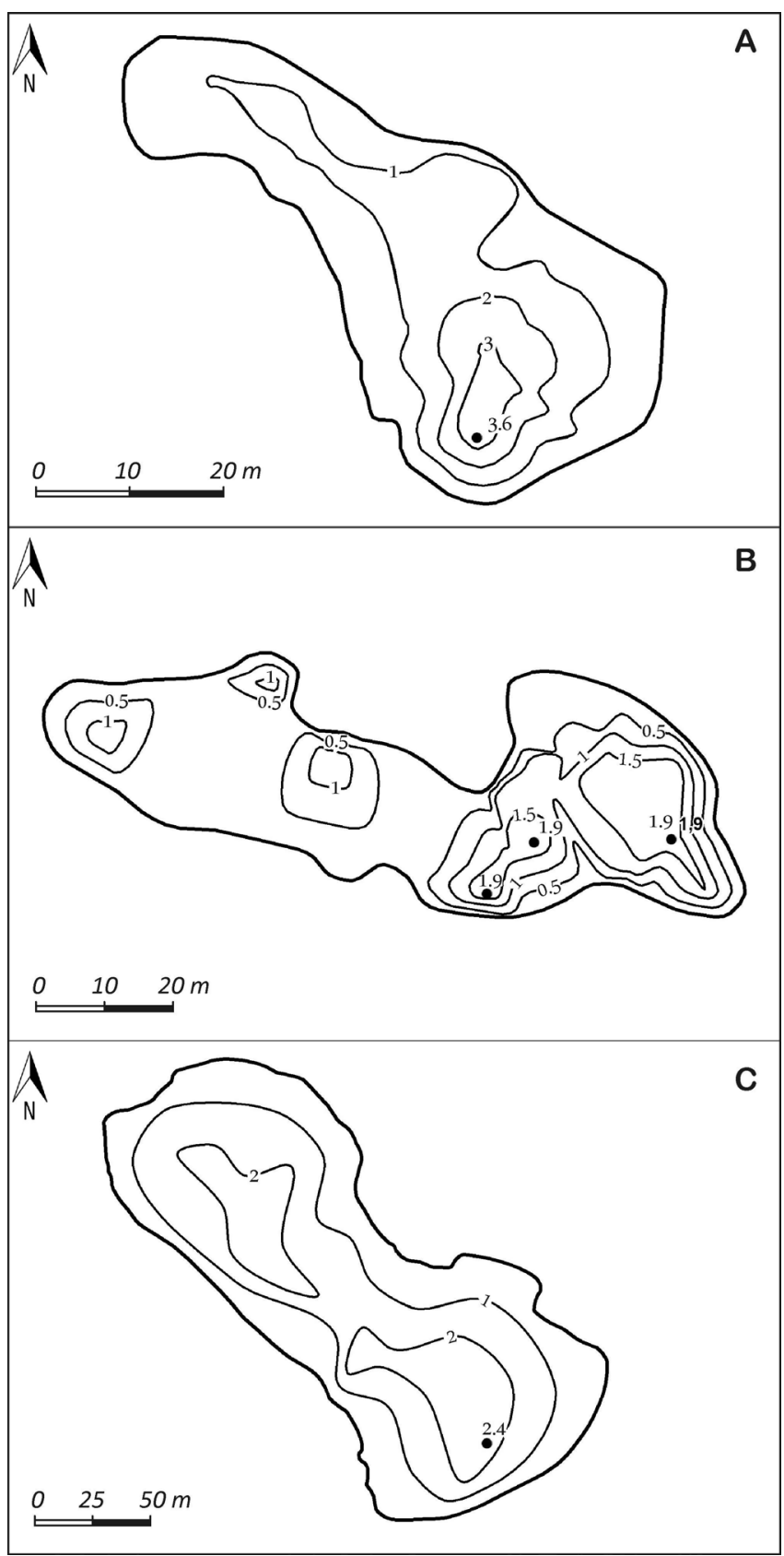

Fig. 3. Bathymetric maps: A - lake in Stawiany village, B - Lake Moczydło, C - Lake Bronina 
nat and Sobieszczański 2003), and Lake Ruda (Biernat and Gwiazda 2003). Parameters characterising the lake basin were determined based on the methodology proposed by Choiński (2007), in which the shoreline development was determined as the ratio of the length of the shoreline to the circumference of a circle of an area equal to that of the lake, and relative depth was calculated in accordance with the Halbfass formula (the ratio of maximum depth to the square root of the lake surface area).

The analysed lakes are small in terms of surface area, and show low mean depths, suggesting low water resources. The lake basins are very diverse in terms of shape. Lake Stawiany has a concave basin, Moczydło conic, and Bronina parabolic. Exceptionally low values of exposure indices suggest that external conditions have a minimal effect on the lakes. Low values are also reached by compactness indices, pointing to low water resources in comparison to the surface areas. In the case of Lake Moczydło, field research (8 October 2019) by Jan Starus showed complete disappearance of water Figure 1D. Therefore, the lake can be described as intermittent.

Figure 4 presents vertical distributions of temperature, $\mathrm{pH}$, oxygen, and conductivity. Field measurements were performed on 20 and 21 June 2012. Lakes Stawiany, Bronina, and Moczydło are examples of karst lakes, and Lake Elżbiety in Michala Góra is a lake of aeolian origin. Despite the low depths, extreme variability of the analysed parameters was observed in some cases. Therefore measurements were performed every $10 \mathrm{~cm}$. The procedure permitted capturing even minimum changes in the analysed measurement profiles.

Water temperature in the case of Lake Bronina shows that the epilimnion has a thickness of only $0.8 \mathrm{~m}$, and the layer with features of the metalimnion reaches the bottom, i.e. a depth of $2 \mathrm{~m}$, whereas the gradient is approximately $4^{\circ} \mathrm{C}$ per metre (Fig 4A). In the case of the remaining lakes, decreases in temperature towards the bottom are several times higher. For Lake Stawiany, the decrease in temperature from the surface to the bottom is relatively uniform, and equals $8.8^{\circ} \mathrm{C}$ to the bottom, i.e. to a depth of $3.6 \mathrm{~m}$. Even greater gradients of temperature decrease occur in the two remaining lakes. Both Lakes Elżbiety and Moczydło have a shallow epilimnion, i.e. only to a depth of $0.5 \mathrm{~m}$. Below that depth, temperature drastically decreas- es to the bottom, i.e. to a depth of approximately $1.5 \mathrm{~m}$. From a depth of $0.5 \mathrm{~m}$ to $1.0 \mathrm{~m}$, temperature decreases by $6.7^{\circ} \mathrm{C}$ per $0.5 \mathrm{~m}$ for Lake Moczydło, and by $8.4^{\circ} \mathrm{C}$ per $0.5 \mathrm{~m}$ for Lake Elżbiety. These are extremely high values.

Water reaction showed high variability (Fig. 4B). Water in Lakes Stawiany and Bronina is strongly alkaline, with a $\mathrm{pH}$ above 8.5. Water in Lake Moczydlo is weakly alkaline, with a pH from 7.5 to 8.5. Water in the aeolian Lake Elżbiety is acidic, with a pH from 4 to 5 .

Like its reaction, oxygen saturation of water shows a very broad range (Fig. 4C). Maximum oxygen contents are between approximately 0.5 and $1.0 \mathrm{~m}$, with lowest values at the bottom. The lowest values of dissolved oxygen are observed in the waters of Lake Elżbiety, down to a trace amount at the bottom, i.e. only $0.06 \mathrm{mg} \mathrm{dm}^{-3}$.

Conductivity of waters in the analysed lakes in vertical profiles shows considerable variability, and in the case of Lakes Elżbiety and Bronina it is practically vertically uniform (Fig. 4D). Substantial differences in the index occur between particular lakes. Lake Elżbiety shows water conductivity several times lower than that in Lakes Moczydło and Bronina, and a dozen times lower than in Lake Stawiany.

The high variability of the waters of the small lakes presented above particularly results from three factors, namely the character of the lakes' catchment areas, variable shading of the water surface from atmospheric factors, and to a great extent, from groundwater supply to the lake basins. Groundwater supply is responsible for the exceptional temperature distributions in the vertical profiles. Intensive groundwater supply was evidenced by the fact that during measurements temperatures in some vertical profiles and measurement points showed differences at a level of $0.5^{\circ} \mathrm{C}$ at a given moment. This points to a fluctuating supply of groundwaters. Temperature was also measured in wetlands at the southern shore of Lake Elżbiety. At the land and water interface the temperature was $22.3^{\circ} \mathrm{C}, 2 \mathrm{~m}$, south of which point it decreased to $20.1^{\circ} \mathrm{C}, 5 \mathrm{~m}$ from the shore the temperature was $15.8^{\circ} \mathrm{C}$, and $9 \mathrm{~m}$ from the shore it was only $13.9^{\circ} \mathrm{C}$. 

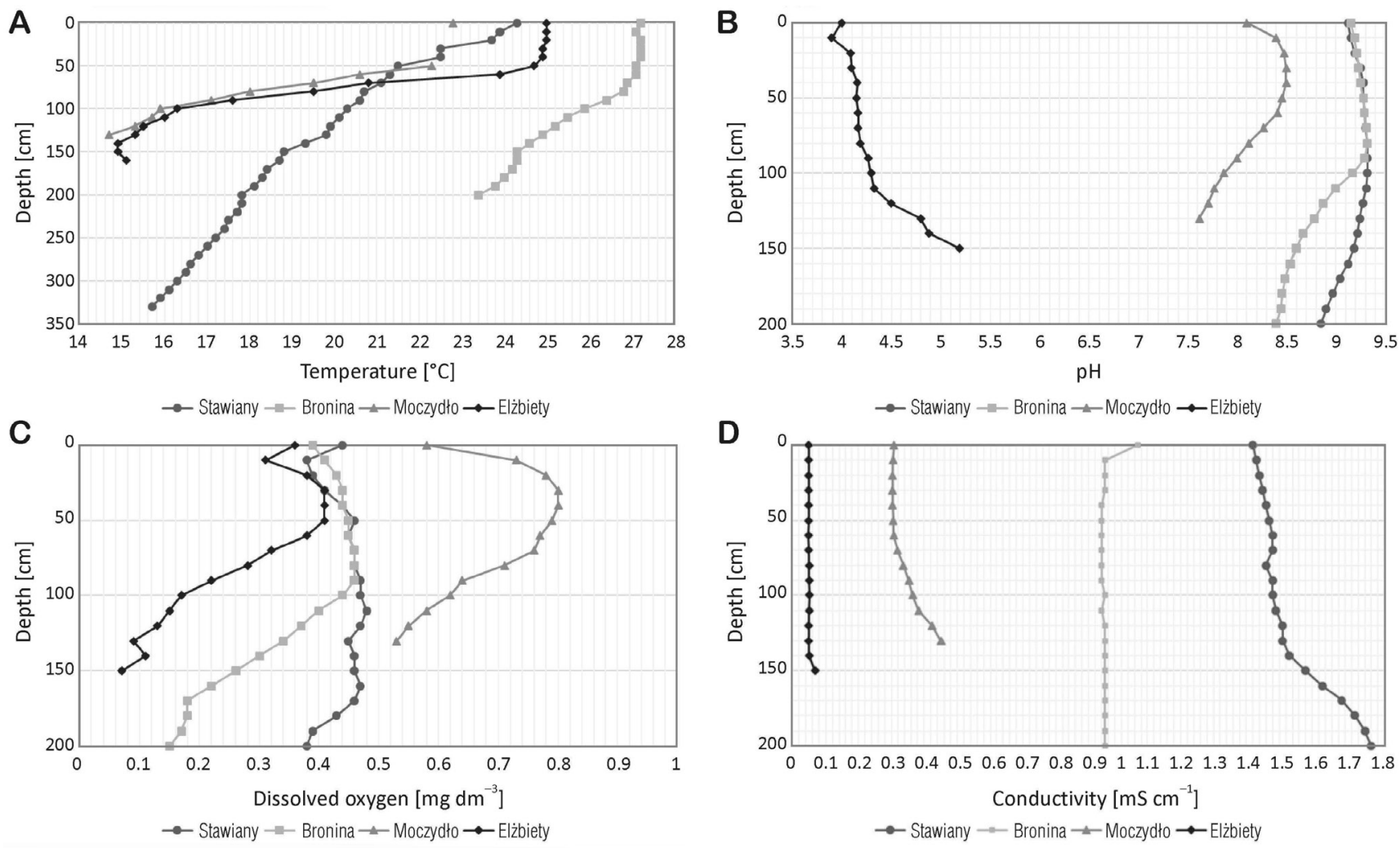

Fig. 4. Vertical profiles of water temperature (A), $\mathrm{pH}(\mathrm{B})$, dissolved oxygen (C), and conductivity (D)

\section{Conclusions}

The first implementation of the research should be recognised as appropriate. It results from the different character of the morphology of the catchment areas of the analysed lakes in comparison to those located within the range of the last glaciation. Although the selected lakes are located close to one another, their bottom sediments show considerable variability. Bottom sediments in the analysed lakes are generally characterised by a substantial content of organic matter. They also show a relatively high variability of physical and chemical water properties. The analysed lakes are exceptional in these terms. On the one hand, they are vastly different from one another, and on the other hand, they show extreme values of some indices, e.g. a very high temperature gradient, or extremely low water acidity. Moreover, some of the lakes in the Swiętokrzyski Region can be of intermittent character. Despite low water resources, the analysed lakes can be exceptionally useful as refugia, and therefore can become valuable study objects for biologists. Although the above results should be considered preliminary, their future expansion is strongly justified.

\section{References}

Biernat T., 2001, Projekt badań limnologicznych w Regionie Świętokrzyskim i wstępne wyniki (Limnological research project in the Holy Cross Region and the preliminary results) [Abstract], [in:] Ciupa T., Kupczyk E. (eds), Wpływ użytkowania terenu i antropogenicznych przekształceń środowiska przyrodniczego na elementy obiegu wody w zlewni rzecznej. Materiały konferencyjne (Impact of land use and anthropogenic transformation of the natural environment on the elements of the water cycle in the river basin. Conference materials), Wydaw. IG AŚ, Kielce: 17-19 (in Polish).

Biernat T., Gwiazda P., 2003, Parametry morfometryczne Jeziora Ruda w okolicy Rudy Zajączkowskiej (Morphometric parameters of Lake Ruda in the area of Ruda Zajączkowska) [Abstract], [in:] VII Ogólnopolska Konferencja Limnologiczna nt. Naturalne i antropogeniczne przemiany jezior. Materiały konferencyjne (VII Polish Limnological Conference on Natural and anthropogenic transformation of lakes. Conference materials), Wydaw. IG AŚ, Kielce: 105-116 (in Polish).

Biernat T., Sobieszczański K., 2003, Warunki przyrodnic- 
zo-krajobrazowe i parametry morfometryczne jeziora Elżbiety koło Michalej Góry (Natural and landscape conditions and morphometric parameters of Elżbieta Lake near Michala Góra) [Abstract], [in:] VII Ogólnopolska Konferencja Limnologiczna nt. Naturalne i antropogeniczne przemiany jezior. Materiały konferencyjne (VII Polish Limnological Conference on Natural and anthropogenic transformation of lakes. Conference materials), Wydaw. IG AŚ, Kielce: 93-101 (in Polish).

Choiński A., 1995, Katalog jezior Polski. Część 3: Pojezierze Wielkopolsko-Kujawskie i jeziora na południe od linii zasięgu zlodowacenia bałtyckiego (Catalogue of Polish lakes. Part 3: Greater Poland-Kuyavian Lake District and lakes south of the Baltic glaciation range line), Wydaw. Nauk. UAM, Poznań, 149 pp (in Polish).

Choiński A., 2007, Limnologia fizyczna Polski (Physical limnology of Poland), Wydaw. Nauk. UAM, Poznań, 547 pp (in Polish).

Choiński A., Ławniczak A., Ptak M., 2016, Changes in water resources of Polish lakes as influenced by natural and anthropogenic factors, Pol. J. Environ. Stud. 25(5): 1883-1890.

Choiński A., Ptak M., 2009, Lake infill as the main factor leading to lake's disappearance, Pol. J. Environ. Stud. 18(3): 347-352.

Choiński A., Ptak M., Strzelczak A., 2014, Present-day evolution of coastal lakes based on the example of Jamno and Bukowo (the Southern Baltic coast), Oceanol. Hydrobiol.l Stud. 43(2): 178-184.

Jaśkowski B., Sołtysik R., 2000, Geneza i wiek Pojezierza Świętokrzyskiego oraz walory przyrodniczo-krajobrazowe jego elementów wodno-torfowiskowo-wydmowych (Origin and age of the Holy Cross Lakeland and the natural and landscape values of its waterpeat-dune elements), [in:] Radwan S., Lorkiewicz Z. (eds), Problemy ochrony i użytkowania obszarów wiejskich o dużych walorach przyrodniczych (Problems of protection and use of rural areas with high natural values), Wydaw. UMCS, Lublin: 137-142.

Jaśkowski B., Sołtysik R., 2001, Jeziora Pojezierza Świętokrzyskiego jako ważny element sieci hydrograficznej na tle przemian środowiska przyrodniczego z uwzględnieniem wpływu antropopresji (Lakes of the Holy Cross Lake District as an important element of the hydrographic network against the background of changes in the natural environment, including the impact of anthropopressure), [in:] Ciupa T., Kupczyk
E. (eds), Wpływ użytkowania terenu i antropogenicznych przekształceń środowiska przyrodniczego na elementy obiegu wody w zlewni rzecznej (Impact of land use and anthropogenic transformation of the natural environment on the elements of the water cycle in the river basin. Conference materials), Wydaw. IG AŚ, Kielce: 46-49 (in Polish).

Jaśkowski B., Sołtysik R., 2003, The origin and age of the lakes of the Świętokrzyski Lake Distict, Limnol. Rev. 3: 101-106.

Kirviel P., Zieliński A., Choiński A., 2012, Ice conditions of lakes in Przedborska Upland and Nida Trough [Abstract], [in:] Grześkowiak A., Nowak B (eds), Natural and antrhropogenic transformations of lakes. Conference materials of the International Limnological Conference "Natural and antrhropogenic transformations of lakes, IMWM - Nacional Research Institute, Branch in Poznań, Poznań: 50-51.

Kukiełka M., Pieńkowski Ł., 2005, Charakterystyka Pojezierza Świętokrzyskiego (Characteristics of the Holy Cross Lake District), [in:] Machowski R., Rzętała M.A (eds), Z badań nad wpływem antropopresji na środowisko. Tom 6 (From research on the impact of anthropopression on the environment. Vol. 6), SKNG UŚ, Sosnowiec: 131-135 (in Polish).

Solon J., Borzyszkowski J., Bidłasik M., Richling A., Badora K., Balon J., Brzezińska-Wójcik T., Chabudziński Ł., Dobrowolski R., Grzegorczyk I., Jodłowski M., Kistowski M., Kot R., Krąż P., Lechnio J., Macias A., Majchrowska A., Malinowska E., Migoń P., MygaPiątek U., Nita J., Papińska E., Rodzik J., Strzyż M., Terpiłowski Sł., Ziaja W., 2018, Physico-geographical mesoregions of Poland. Verification and adjustment of boundaries on the basis of contemporary spatial data, Geogr. Pol. 91(2): 143-170.

Stachura M., Wieczorek D., Zieliński A., 2018, An attempt at a typology of karst lakes in the Połaniec Basin (Małopolska Upland, Poland), Bull. Geogr. Phys. Geogr. 15: 63-74.

Zieliński A., 2010, Wstępne badania właściwości fizyczno-chemicznych wód jezior w Lasach Golejowskich koło Staszowa, Niecka Połaniecka (Preliminary studies of the physico-chemical properties of lake waters in Golejowskie Forests, Połaniecka Basin), [in:] Ciupa T., Suligowski R. (eds), Woda w badaniach geograficznych (Water in geographical studies), IG UJK, Kielce: 253-259 (in Polish, English summary).

Zieliński A., 2013, Rozwój jezior krasowych w Niecce Połanieckiej (Development of karst lakes in Połaniec 